\title{
Political or Financial Benefits? Ideology, Tenure, and Parliamentarians' Choice of Interest Group Ties
}

This article develops and tests a parliamentarian-centred decision model of the collaboration between interest groups (IGs) and parliamentarians. We posit that parliamentarians face a trade-off when deciding on IG ties that offer them either political (policy support and votes) or financial benefits (additional income). We theorise the balance in this trade-off to be moderated by ideology and tenure because both introduce variations in IG ties' utility across politicians. Using Swiss longitudinal data from 1985 to 2015 on 743 parliamentarians and their 5,431 IG board positions, we show that parliamentarians become more financial benefitseeking over time. This holds in particular if they belong to right-leaning parties. We also find self-imposed restrictions for new and left-leaning parliamentarians on seeking financial benefits. This highlights that parliamentarians are responsive to their partisan constituents when building their IG tie portfolio.

Keywords: parliamentarians; interest groups; responsiveness; moonlighting; voteseeking

Words: 9,526

\section{Introduction}

This article scrutinises how parliamentarians prioritise different kinds of extra-parliamentary activities. Popular rational choice approaches commonly model the behaviour of politicians as either office-seeking (Downs 1957) or policy-seeking (Wittman 1977, 1983). While undeniably important, the actions of parliamentarians cannot be explained with exclusively political drivers in mind. This in particular applies to understanding extra-parliamentary activities. A broad range of studies has demonstrated that members of parliament (MPs) do not only seek office and policy but also personal financial benefits. While in office, they use their mandate to accrue additional earnings from extra-parliamentary activities (Becker et al. 2009; Gagliarducci et al. 2010; Geys 2013; Geys and Mause 2012; Hurka et al. 2018) and as a springboard for lucrative post-parliamentary careers (Diermeier et al. 2005; Eggers and 
Hainmueller 2009; Maddox 2004). However, despite the emphasis on political benefit-seeking in parts of the literature (e.g. Downs 1957; Wittman 1977) and financial benefit-seeking in another part (e.g. Diermeier et al. 2005; Geys and Mause 2013) little is currently known about the combined role of financial and political incentives.

Financial incentives affect MPs' behaviour the moment they take up their seat. We know from previous research that pursuing a legislative career may entail a substantive drop in current wages and the loss of future earnings (Maddox 2004). Legislators, particularly those with high pre-parliamentary earnings have been observed recuperating lost income with extra-parliamentary activities in an attempt to maintain their standard of living (Gagliarducci et al. 2010). At the same time, even independent of losses, MPs are motivated to capitalise on their political office. Previous research shows that outside earnings of incumbent MPs reduce their dependence on re-election and simultaneously provide a survival insurance for life after parliament (Geys and Mause 2013).

Pursing this topic carries substantial relevance because previous research has shown financial benefit-seeking to have detrimental implications for policy-seeking and vote-seeking behaviour. As MPs' focus on monetary spoils from office increases, their oral contributions in parliament decrease, they use fewer legislative instruments (e.g. interpellations), and they are more frequently absent from parliament (Arnold et al. 2014; Bailer 2011; Gagliarducci et al. 2010). This means that, contrary to the ideal image politicians like to portray, elected representatives are typically balancing personal financial considerations with ideological policy-seeking and vote-seeking ones.

Looking at such dynamics through an analytical lens, we argue that simultaneously seeking political benefits (i.e. office and policy) and financial benefits introduces a trade-off dynamic. Evidence for this idea is presented by survey experiments in the United Kingdom where higher outside earnings resulted in lower electoral support for politicians (Campbell and Cowley 2015). Hence, if parliamentarians only sought to make a career in politics and advance their policy goals, we should not observe parliamentarians with extra-parliamentary activities for primarily financial self-interests. The real world tells a different story though. This raises the question why MPs engage in activities that jeopardise their political endeavours. And more fundamentally, this also allows us to address the broader question about MPs' responsiveness to voters. Under what conditions do interests of the electorate take a backseat to personal financial gains? 
For studying this trade-off dynamic, parliamentarians' board positions in interest groups (IGs) provide an excellent opportunity. Both for MPs' political goals (office-seeking and policy-seeking) as well as their pursuit of financial benefits, IGs play a crucial role. In return for access to parliament, IGs can provide political support as well as financial benefits. Some IGs, like firms, primarily offer financial benefits while others, like labour unions, primarily provide political benefits. In return, MPs become interest groups' advocates in parliament (Gava et al. 2016; Niessen and Ruenzi 2010) which often has a direct impact on their behaviour in parliament (Arnold et al. 2014; Gagliarducci et al. 2010; Staat and Kuehnhanss 2016). Yet, although there are clearly good reasons for representatives to pursue both political and financial goals, existing studies have so far primarily looked at this relationship through the lens of access-seeking IGs and attributed the agency accordingly (Fouirnaies 2018; Fouirnaies and Hall 2014; Fouirnaies and Hall 2018; Neff Powell and Grimmer 2016). This leaves a research gap when it comes to understanding the parliamentarian-side of the IG-MP collaboration equation.

While IGs' decisions are undoubtedly important, we purposefully aim our theoretical and empirical attention to MPs' point of view. We formulate an MP-centred decision model of interest group collaboration. To study MPs' pursuit of political and financial goals in conjunction, we focus on the relative proportion of financial benefit-generating versus political benefit-generating interest group ties that MPs hold. The empirical validity of our model is tested with detailed yearly information on the 5,431 long-term interest group ties of 743 Swiss parliamentarians from 1985 to 2015. By investigating the impact of tenure and political ideology on collaboration with representationally focussed interest groups and firms, we aim to shed light on the conditions that cause MPs to relax on their pursuit of constituency and policy interests and instead focus on personal income.

Our article offers three key innovations. First, we attempt to solve the puzzle of when MPs invest in either their voters and their policies, or themselves. We contribute to answering this question by dividing MPs' IG tie seeking behaviour into financial benefit-seeking (using firm boards for personal financial gains) and political benefit-seeking (using board positions at IGs to garner electoral and policy support). As a second contribution, we ensure that a potential relation between right-leaning ideology and financial benefit-seeking cannot be attributed to ties that already formed in the pre-parliamentary stage. We do this by using longitudinal data and statistically controlling for the proportion of financial benefit-generating 
ties that MPs have when they enter parliament. This allows us to longitudinally study the constitution and alteration of collaboration patterns across the parliamentary career. Third and finally, we move beyond the general descriptive observation that MPs from the centre and right side of the political spectrum hold more private sector ties (Arnold et al. 2014; Kerr 1981; Maddox 2004; Mause 2009). Instead, we address the dynamics responsible for this wellestablished pattern by conceptualising the incentive structure that left-leaning and rightleaning MPs face, thus exploring the underlying causal mechanism.

The empirical investigation reveals that parliamentarians become increasingly financial benefit-seeking over time. This holds in particular if they belong to right-leaning parties but does not apply to left-leaning MPs.

\section{What Interest Group Ties Do Parliamentarians Seek When?}

The starting point for our theoretical model is MPs' decision to work with one or multiple interest groups. We propose a model that focuses on the relative composition of MPs' IG portfolio because this allows us to set aside the absolute amount of time invested in extraparliamentary activities. ${ }^{1}$ Our baseline model hinges on four premises.

First, parliamentarians derive one of two types of utility from every interest group mandate: political benefits (support for policy and garnering votes) or financial benefits (income). Financial benefit-generating ties primarily provide lucrative salaries. They are construed to function foremost as a source of income and not political benefits. Conversely, political benefit-generating ties primarily serve the purpose of attracting voters and securing political support for MPs' policies. While financial remuneration for political benefitgenerating ties is possible, it is assumed that pecuniary motives for holding them are not centre stage.

Second, we posit that the final decision on tie formation generally lies with parliamentarians: in analogy to job recruitment in other professional domains, the last step in the decision chain will be MPs' acceptance or refusal of an IG board position offer. This assumption holds notwithstanding that board offers from IGs are patterned (e.g. by ideology, committee positions, regional background etc.). The basic intuition behind this assumption is

1 This helps avoid changes in time availability over time. For instance, MPs' absolute time availability for IG board positions can be expected to increase over time as they become more efficient as parliamentarians and in their roles on IG boards. 
that to accept one (additional) financial benefit-generating tie an MP only needs one, not multiple, offers. Indeed, supply dynamics are arguably less important because receiving more offers from certain IG types cannot be equated with accepting them. ${ }^{2}$ This holds particularly true for portfolios consisting of a lower total number of ties (in the Swiss case an average of 5 ties per MP). Moreover, MPs may also actively seek out board positions. This suggests that all MPs could fill their tie portfolio with either exclusively political benefit-generating or financial benefit-generating ties.

Third, our model assumes that MPs behave in a utility-optimising manner. When they decide to form an (additional) financial benefit-generating or political benefit-generating tie, MPs weigh the expected positive and negative ramifications of that tie. They strategically decide on a portfolio of ties which they believe will benefit them most. Depending on specific incentives (e.g. career stage, ideology of the party), we expect MPs to include relatively more ties of one of these types in their portfolio.

Fourth, parliamentarians' decisions on their IG tie portfolio is affected by time availability. Increasing the share of either political benefit-generating or financial benefitgenerating ties comes at the cost of reducing the share of the respective other IG tie type. Hence, MPs face a trade-off between investing their time in political benefit-generating and financial benefit-generating ties. ${ }^{3}$ Figure 1 , (top left graph) illustrates this trade-off as a basic utility function which forms the basis of our theoretical reasoning. Under conditions of nonpartisanship, lack of tenure, and the absence of inherent preferences, we for now assume that the utility MPs derive from political benefit-generating and financial benefit-generating ties are perfect substitutes.

Having established the baseline model, we will now deduct predictions from it. For our first hypothesis $\left(\mathrm{H}_{1}\right)$, we introduce differences in static incentives. We posit that the utility MPs derive from financial benefit-generating ties differs depending on the ideology of the party they are representing. MPs' financial benefit-generating ties often conflict with their representative role (Campbell and Cowley 2015; Chappell 1981; Geys 2013; Niessen and

2 To use an analogy: If one searched online for a city trip to Paris once, all the online advertisements might be about city trips to Paris afterwards. However, this does not mean that all of one's future trips will be to Paris.

3 The theorised trade-off dynamic can also be observed in the data. In 57.9 per cent of all cases, MPs held either none or only firm board positions (see Online Appendix). 
Ruenzi 2010: 449). Financial benefit-generating ties have been construed to weaken the bond between voters and parliamentarians, thus ultimately posing a threat to (re-)election chances.

This vote penalty, however, does not affect all parliamentarians equally. Various studies have shown that centre-right-wing parties typically maintain primarily ties with (resource-rich) business interest groups and left-wing parties are strongly connected to groups representing public interests (Maddox 2004; Mause 2009; Wonka 2017). This makes sense because both voters and representatives have an image of what an appropriate interest group tie looks like on basis of an MP's ideology. For example, it seems particularly inappropriate to hold a firm board position at a multinational company for a member of the socialist party. As MPs' individual positions are relatively difficult to perceive for voters (cf. Marquis 2010: 427), we assume that voters will judge the appropriateness of IG ties by party cues.

Admittedly, voters will rarely, if ever be aware of MPs' complete tie portfolio. Nonetheless, parliamentarians face a substantial risk that controversial board positions will become publicly well-known. They fear that voters will perceive these ties as infringing on the principles and values of their party. Politicians of more left-leaning parties will thus have stronger inhibitions to work for financial benefit-generating IGs not because of high salaries but because of the pro-business positions they entail. In anticipation of repercussions, these MPs are deterred from taking up such atypical board positions. Compared to the baseline model, the utility of financial benefit-generating ties relative to political benefit-generating ties for left-leaning MPs is therefore reduced.

For the same reason, MPs on the centre-right of the ideological spectrum can assume relatively more financial benefit-generating ties. Centre-right MPs are not perceived as violating their principles when holding well-paying side jobs at pro-business IGs. Rather, voters might even see those MPs as keeping in touch with the "real world" (cf. Campbell and Cowley 2015). Right-leaning MPs therefore derive relatively more utility from financial benefitgenerating compared to the baseline model - and compared to left-leaning MPs (Figure 1, top right graph). Hence, we can formulate our first, static expectation that:

$H_{1}$ The more right-leaning MPs are, the more they will hold financial benefitgenerating ties over political benefit-generating ties.

Differences in utility from the two tie types are not only static though. For our second hypothesis $\left(\mathrm{H}_{2},\right)$ we introduce dynamic (time-dependent) incentives. More specifically, we derive how utility will vary according to MPs' tenure. Key to this argument is that an 
incumbency bonus reduces MPs' dependency on votes and hence their utility derived from political benefit-generating ties.

Incumbent parliamentarians typically enjoy an electoral advantage over their challengers (Ansolabehere and Snyder 2002; Gelman and King 1990), which is also true in the Swiss case (Lachat 2006). Their office helps them foster votes by bringing about favourable legislation for their district and funnelling resources towards their constituents (Cain 1987). At the same time, benefits from their established position are further reinforced as they enjoy increased attention from journalists as tenure rises (van Aelst et al. 2010). In consequence, MPs' dependence on interest group ties for gaining votes decreases. It allows them, in relative terms, to pursue financial benefit-generating ties more liberally as the utility of interest group ties to generate votes diminishes (Figure 1, bottom left graph). We can therefore formulate our second, dynamic expectation that:

$\mathrm{H}_{2}$ The more MPs' tenure increases, the more they will hold financial benefitgenerating ties over political benefit-generating ties.

Finally, we consider it important to combine static and dynamic incentives. The focus of our third hypothesis $\left(\mathrm{H}_{3}\right)$ is on the interplay between ideology and tenure (Figure 1, bottom right graph). In terms of static incentives, we previously hypothesised that right-leaning parliamentarians derive a higher utility from financial benefit-generating ties than from political benefit-generating ties $\left(\mathrm{see}_{1}\right)$. At the same time, we posited that dynamic incentives decrease the utility of political benefit-generating relative to financial benefit-generating ties over time (see $\mathrm{H}_{2}$ ).

Combining these two effects leads us to expect that particularly right-leaning MPs will increase their share of financial benefit-generating ties in their tie portfolio over the course of their tenure: Already at the outset of their parliamentary career, right-leaning MPs have a higher incentive to opt for relatively more financial benefit-generating positions. This effect is further aggravated as their tenure progresses. The lower utility of political benefit-generating ties further decreases. At the same time, the utility of financial benefit-generating ties likely remains the same in absolute terms. In consequence, financial benefit-generating ties become even more attractive in relative terms. Therefore, we should observe that as tenure increases, more right-leaning parliamentarians opt for higher shares of financial benefit-generating ties in their portfolio. 
$\mathrm{H}_{3}$ The more right-leaning MPs' tenure increases, the more they will hold

financial benefit-generating ties over political benefit-generating ties.

In contrast to right-leaning MPs $\left(\mathrm{H}_{3}\right)$, our theoretical model does not permit us to derive clear expectations for the interplay of ideology and tenure for left-leaning parliamentarians. This issue arises because we derived two counteracting effects from our model but do not have much to build on when it comes to the relative size of these effects. Hence, we cannot derive which effect prevails.

On the one hand, our model posits that the utility of political benefit-generating ties decreases over tenure for all MPs. On the other hand, left-leaning MPs derive more utility from political benefit-generating ties than from financial benefit-generating independent of time.

This provides room for two probable scenarios. First, it is possible that over time, leftleaning MPs' marginal utility from political benefit-generating ties decreases to the extent where it is below that of financial benefit-generating ties. If this point were reached, we could expect left-leaning MPs to start investing relatively more of their time into financial benefitgenerating ties. Second, it is, however, also possible that for them, the marginal utility of political benefit-generating ties never falls below that of financial benefit-generating ties during the parliamentary career. In that case, we should observe that left-leaning MPs increase their relative share of political benefit-generating ties at any point in their career. Our empirical results also aim to shed light on this question.

[Figure 1 about here]

\section{Case Selection}

Our theoretical model is applied to the lower house of the Swiss Parliament. The 200-member National Council lends itself well to studying the topic under scrutiny. In comparison to other legislatures, the Swiss parliament ranks among the least professionalised, scoring second last of all OECD countries in terms of salary. Simultaneously, MPs are nonetheless fully occupied with parliamentary work, particularly for committees while they receive almost no resources to shoulder this burden (Sciarini et al. 2017; Z'graggen and Linder 2004). This provides MPs with ample motives to accept financial support from IGs. It has been said that the question for Swiss MPs is not so much whether they want to work with IGs but rather with whom (Gallati 
2005: 83). The Swiss parliament is on that account a most-likely case for seeking financial benefits. The relative attractiveness of policy support and votes versus additional income is thus weaker than in other countries. Switzerland is therefore a hard case for finding support for our trade-off argument.

Also in terms of generalisability, a strong argument is to be made for the Swiss case. Since 1985, the Swiss Parliament has maintained a lobby register where MPs report their positions on leadership boards, supervisory bodies, and advisory boards of both private and public organisations (see Online Appendix for more information). Together with 44 other countries (out of 177), Switzerland is part of a large group of countries where disclosure regulations and laws provide citizens with access to MPs' financial and/or business interests (Djankov et al. 2010). By studying the Swiss case, we also gain insights into a broad number of other country contexts.

\section{Data and Operationalisation}

The data for this study are provided by the research project Parliamentary Careers in Comparison (PCC). ${ }^{4}$ We also partly rely on data provided by Mach et al. (2017). These data enable us to generate our core data that, in addition to several auxiliary variables (e.g. age, gender, occupational career, committee membership), capture National Council members' interest ties on an annual basis from 1985 to $2015 . .^{5}$ Our unit of analysis are 6,225 parliamentarian-year observations. This allows for a detailed assessment of how MP-IG ties develop across the parliamentary career.

\section{Dependent and Key Independent Variables}

Proportion of firm board positions. The dependent variable in our analysis is the proportion of financial benefit-generating to political benefit-generating ties at the beginning of every year. A value of a 100 (percent) signifies that all ties held by an MP are financial benefitgenerating. If none of the IG positions are financial benefit-generating the measure takes on a value of 0 . On that account, we categorised all IG type as either financial benefit-generating and political benefit-generating. Financial benefit-generating ties concern positions on the boards of private firms that predominantly serve to supplement MPs' income. In contrast to 
other IG types, political interest representation is not centre-stage for firms. They engage only rarely and selectively in lobbying (Lowery et al. 2004). A representative survey among Swiss parliamentarians conducted between 2004 and 2005 found that MPs earned on average $16,540 \mathrm{CHF}$ from side jobs ${ }^{6}$ (Baeriswyl 2005). It is reasonable to assume that a large share of this sum can be attributed to private firm ties. In contrast, political benefit-generating ties entail IG board positions for representing certain segments of society such as people or organisations with a shared identity and/or common goals, or the provision of public goods. In this category, we include ties to organisations that predominantly help MPs rally political support. Past research has demonstrated that leadership positions on the boards of IGs help candidates receive significantly more preference votes during elections (Lutz et al. 2018). Once elected, the same IG ties help parliamentarians secure support for their policy proposals (Fischer et al. 2019). Our operationalisation is based on the reasonable assumption that these types of side jobs on average often come with much more moderate financial compensation or are even unpaid. Table 1 provides a classification of IG types according to their key benefits.

\section{[Table 1 about here]}

When constructing the dependent variable, three IG types were excluded. Data on board positions in public firms and semi-independent agencies were not used because they are often ex officio tied to specific political offices. Business associations could also not be included in the measure because they arguably provide both types of benefits. Not only are they strong providers of political support (Fischer et al. 2019; Grossmann and Dominguez 2009; Wonka and Haunss 2019), anecdotal evidence also emphasises very attractive salaries. ${ }^{7}$

The resulting measurement is given as the proportion of the two benefit types, or more specifically as:

Proportion of firm ties $=\frac{N_{\text {Firm }}}{N_{\text {Firm }}+N_{\text {Union }}+N_{\text {occupational }}+N_{\text {Identity }}+N_{\text {Institutional }}+N_{\text {Religious }}+N_{\text {Public }}} * 100$

Left-right. The first main independent variable in our analysis focuses on the ideological stances of MPs. This variable ranges from 0 (extreme left) to 10 (extreme right). It

6 At the same time, they earned on average 85,610 CHF from their parliamentary mandate.

7 As a robustness check, we also estimate our models with an alternative dependent variable that considers business associations only as political benefit-generating (see Online Appendix). 
measures the ideological constraints and expectations individual MPs are subject to on basis of their party's ideological position. The measure for left-right is coded by Döring and Manow (2018). It constitutes the unweighted mean value of quantitative information obtained from several party expert surveys between 1983 and 2006. ${ }^{8}$ This party level aggregate measures how MPs expect voters to assess their ideology.

Tenure. The second main independent variable in our analysis measures MPs' time spent in parliament in years. The variable indicates how many years an MP has spent in parliament as of 1 January of a given year.

\section{Control Variables: Contextual Factors ${ }^{9}$}

Election year measures dichotomously whether an election took place in the previous year. We use a one-year lag because our data is based on a source in which MPs report their ties in the beginning of the year.

Seat safety is a measure of parliamentarians' victory margin in the previous election appropriate for the Swiss case. It indicates the certainty with which MPs obtained their seat during the last election. Given the specificities of the Swiss open-list multiple vote electoral system, we developed a measure to optimally fit the Swiss context. This measure takes the number of MPs' personal votes and ranks them in comparison to the other candidates on their list. It then subtracts the rank from the total number of seats won by a list. The last MP from a list that made it to parliament therefore receives a score of 0 . MPs with more votes than the MP at 0 obtain positive integers. Replacement MPs (i.e. MPs who entered parliament between elections to replace a colleague) receive a score of 0 by default.

Last term is a categorical variable. Parliamentarians may either not be in their last term (0), have a planned last-term (1), or have an unplanned last term (2). Planned last terms (1) constitute situations where MPs decide not to run for the next election. We infer this from incidents in which the names of distinct MPs no longer occur on the upcoming ballot. In contrast, unplanned last terms (2) refer to cases where MPs ran, but failed in their bid for reelection or died in office.

8 The left-right score captures almost exclusively the economic positioning of parties. It is almost perfectly correlated with the state-market score that measures parties' stance on market regulation (Pearson's $r=$ 0.95, $\mathrm{p}<0.001)$.

9 Theoretical considerations concerning the inclusion of certain control variables are provided in the online appendix. 
District magnitude indicates the total number of seats available in an electoral district in a given year. In the Swiss electoral system, these seats are awarded on the basis of an open list proportional representation system.

\section{Control Variables: Individual Factors}

Proportion of firm board positions at entry gives the state of MPs' proportion in their earliest year in parliament. For most MPs, this is the proportion one or two months after taking office.

Female is a dichotomous measure for gender $(0=$ male $/ 1=$ female $)$.

Lawyer is a dummy variable for MPs' general attractiveness to companies on the basis of their legal training (Kurtz and Simon 2007).

Firm-relevant committee membership. We code whether MPs held a position in any parliamentary committee or subcommittee in a certain year that dealt with financial and/or economic policy $(0=$ no $/ 1$ = yes $)$.

Regional tenure. Previous political experience is controlled for by two measures, tenure in regional parliament and tenure in regional government in a given year. Both variables give regional tenure in years.

Pension age. The variable pension age captures whether an MP is below (0) or above (1) the Swiss legal retirement age of 65.

\section{[Table 2 about here]}

\section{Analytical Strategy}

Our analysis consists of two parts. In a first, descriptive part we present a set of distribution plots that show the types of side-functions MPs typically hold across their career in parliament. In these graphs, we will highlight the proportion of financial benefit-generating and political benefit-generating ties. If $\mathrm{H}_{1}, \mathrm{H}_{2}$ and $\mathrm{H}_{3}$ are true, these graphs should reveal a pattern where the share of financial benefit-generating ties shifts with ideology $\left(\mathrm{H}_{1}\right)$, increases with parliamentary tenure $\left(\mathrm{H}_{2}\right)$ and particularly so for right-leaning politicians $\left(\mathrm{H}_{3}\right)$. 
In the second, inferential part, we predict the proportion of firm board positions of individual MPs across their parliamentary career. For this we use linear ${ }^{10}$ regression models with parliamentarian and year as random terms. ${ }^{11}$ Our key independent variables are tenure, left-right and the interaction term of these two variables. If $\mathrm{H}_{1}$ is true, the baseline proportion of firm board positions should increase when the parties that politicians represent move towards the right on the left-right scale. If $\mathrm{H}_{2}$ holds, tenure should have a direct positive effect on the proportion of firm board positions. Finally, $\mathrm{H}_{3}$ would be corroborated by a positive estimate on the interaction term of tenure and left-right. We will assess this effect by plotting the difference in the estimated effect of tenure depending on the left-right position of MPs' party.

Our regression model is built up in six steps. First, in pursuit of an empirical judgement for $\mathrm{H}_{1}$, we begin by testing the extent to which the direct relation between left-right and the proportion of firm board positions that has been found in previous studies holds when we control for the relations that existed before first entry into parliament (i.e. when the proportion of firm board positions at entry is added to the model). Subsequently, in the second and third modelling step, we investigate the tendency for MPs from right-leaning parties to hold financial benefit-generating ties over political benefit-seeking ties while in parliament. To measure this, we add tenure $\left(\mathrm{H}_{2}\right)$ and the interaction term tenure*left-right $\left(\mathrm{H}_{3}\right)$ to the equation. Finally, in model four, five and six we add control variables. We consider our hypotheses supported if the hypothesised effects remain substantive and significant when these controls are added. The first set of controls takes into account specific external factors that alter MPs' incentives to select different side jobs (election year, seat safety, last term, district magnitude). A second set of control factors concern the individual characteristics of

Despite the issue with potential negative predicted values, we opted to use regular linear regression instead of binomial regression. We belief that the proportion of firm ties does not come about as the result of independent experiments but is instead dependent on the firm tie proportion an MP already has. Hence, regular linear regression is more appropriate. Figure $\mathrm{V}$ in the appendix shows that the predicted values of the regression model are generally within the valid range of 0 to 100 . Results using a binomial specification are generally robust. Available upon request.

11 We also considered using parliamentarian-fixed effects. Yet, such a model is less appropriate given our interest in several between-parliamentarian effects (e.g. ideology of MPs' party). Instead, we opt to control for the individual level proportion of firm board positions at entry. This approach arguably also controls for a whole set of alternative explanations (e.g. the political human capital of MPs or their specific attractiveness to private sector employers) without the downsides of a fixed-effect conceptualisation for model parsimony. 
MPs that potentially affect their tie selection behaviour (gender, lawyer, firm-relevant committee membership, regional tenure, and pension age).

\section{Descriptive Results}

Figure 2 displays how the distribution of MPs' ties develops as they become more tenured. This first descriptive results show that over the course of their parliamentary careers, Swiss MPs actively forge new interest group ties. While the average parliamentarian enters parliament with 3.4 ties, this count almost doubles to 6.4 ties when they have spent ten years (a bit over two terms) in parliament. This increase interestingly suggests that MPs' might increase their efficiency over time. On the one hand, this might be because they become more efficient board members for the IGs on whose boards they sit. On the other hand, as they spend more time in parliament, they also gain more routine. This might free up time that can be invested in IG board positions.

Figure 2 reveals that this rise is particularly pronounced in the first two years of MPs' tenure. Afterwards, the number of political benefit-generating ties stays relatively stable whereas the number of firm ties continues to grow over tenure.

The increase of ties that serve MPs' personal financial benefits develops relatively constantly as MPs become more tenured. When entering parliament, MPs on average have ties to 1.36 financial benefit-generating IGs. After three terms in parliament, this number has more than doubled to an average of 2.79 financial benefit-generating ties. An additional calculation also reveals this increase to be evident in relative terms. At entry into parliament, less than 30 per cent of MPs' overall ties are to private firms. After ten years in parliament, the average share has risen to 38.1 per cent of firm ties. This provides descriptive evidence that, as $\mathrm{H}_{2}$ posits, the share of firm board positions increases over MPs' tenure.

\section{[Figure 2 about here]}

Having established this general trend, we can, in a second descriptive step, turn our attention to the difference between left-leaning and right-leaning MPs. Left-leaning MPs as depicted in Figure 3 encompass parliamentarians from parties with a left-right score $<4.729^{12}$ (e.g. SP/PS,

12 This cut-off value was chosen to use the Christian democrats (CVP/PDC) as the boundary centre rightleaning party between left-leaning and centre-right-leaning MPs. This represents the Swiss case better than a mid-scale cut-off of 5.0 . 
GPS/ PES, GLP/PVL), centre and right-leaning MPs belong to parties with a score $>=4.729$ (e.g. CVP/PDC, FDP/PLR, LPS/PLS, BDP/PBD, SVP/UDC). Figure 3 suggests that left-leaning, and centre and right-leaning parliamentarians indeed accumulate different types of ties.

When it comes to the different propensities to seek out political benefit-generating ties we see that right-leaning and left-leaning MPs depict differences from the outset of their parliamentary careers. Centre and right-leaning MPs hold on average 1.38 political benefitgenerating ties when entering parliament, left-leaning MPs 1.66. Over time the absolute difference becomes slightly larger. After 10 years, left-leaning MPs hold on average 3.11 political benefit-generating ties and their right-leaning colleagues have 2.55 .

We observe that in comparison to left-leaning MPs, right-leaning MPs show a clear tendency to cultivate ties to private firms $\left(\mathrm{H}_{2}\right)$. When first taking up their seat, left-leaning MPs hold on average ties to 0.60 private firms. For right-leaning MPs, this number is also nearly three times as large (1.76). This supports the need to statistically control for the proportion of firm board positions upon entry to better establish causal inference. On top of this base-line pre-parliamentary difference, we can, however, also see that this difference between left-leaning and right-leaning MPs increases further over time $\left(\mathrm{H}_{3}\right)$. While centre and right-leaning MPs held on average 3.29 firm board positions after ten years in parliament, the number for left-leaning MPs stays relatively stable (0.55 firm board positions). This is noteworthy as it offers some evidence that political benefit-generating ties maintain a higher marginal utility for them than financial benefit-generating ties as their tenure increases.

\section{[Figure 3 about here]}

\section{Multivariate Results}

Table 3 reports the results of the multivariate regression models where we predict the proportion of firm board positions over the parliamentary career. They corroborate our theoretical assumptions. In line with $\mathrm{H}_{1}$, the results in Table 3 reveal that a stronger right-wing ideology is indeed associated with a higher proportion of financial benefit-generating ties even when the proportion of ties at entry (i.e. pre-parliamentary IG affiliations) is controlled for. For every one unit move to the right on the 10-point ideology spectrum, MPs increase their proportion of firm board positions across their entire parliamentary career by an estimated $2.15[1.51,2.80]$ per cent (Model 1). With an average of about five ties, this means that far- 
right MPs in comparison to far-left ones are estimated to - on average - accumulate one full additional tie across the parliamentary career $(2.15 \% * 10=\sim 21.5 \%-0.215 * 5=1.075)$.

The results we report in Table 3, Model 2 also corroborate $\mathrm{H}_{2}$. An increase in tenure results in an increase in the proportion of firm board positions. Yet, compared to ideology, the average overall substantial impact for MPs from left-leaning and right-leaning parties combined is relatively small. On average for all MPs, for an additional year spent in parliament, the share of financial benefit-generating ties increases by roughly 0.23 per cent $[0.08,0.38]$.

To obtain an image of potential heterogeneity in the effect of tenure across ideology the third step of our multivariate analysis addresses the interplay between ideology and tenure $\left(\mathrm{H}_{3}\right)$. To assess this, we plot the specific estimated effects of tenure for three large political parties. Figure 4 demonstrates that right-leaning MPs indeed significantly increase the proportion of their financial benefit-generating ties over the course of their tenure. This is in line with $\mathrm{H}_{3}$.

Recall that for left-leaning parliamentarians, we could not derive if their hypothesised increased dynamic tendency to pick up financial benefit-generating ties was going to outweigh their static tendency to not do so. The results in Figure 4 also shed light on this. We observe that the proportion of firm board positions decreases over time for left-leaning MPs. This suggests that the decrease in utility of political benefit-generating ties over time never reaches a level where the absolute utility of political benefit-generating ties is below that of financial benefit-generating ties.

\section{[Figure 4 about here]}

Moving our attention to the control variables, the presented results provide some interesting insights into the behavioural consequences of contextual factors. Model 6 in Table 3 for example suggests that during election years, parliamentarians increase their share of financial benefit-generating ties by $4.27[2.08,6.43]$ per cent compared to non-election years. This provocatively suggests that being at political crossroads does not lead MPs to invest more into their political career by seeking political benefit-generating ties. Instead, it incentivises MPs to seek out potential career options outside of parliament.

This interpretation is further strengthened by the finding that for every rank that MPs move closer to the last politician on their party list who made it to parliament (i.e. as the 
safeness of the seat decreases), the share of firm board positions is increased by 1.00 [0.47, 1.54] per cent. This seat safety variables ranges from 1 to 11 . Hence, this constitutes a substantial and noteworthy effect where MPs' electoral vulnerability seems to stimulate the cultivation of relatively more financial benefit-generating ties.

For personal characteristics, three control variables produce notable effects. First, we find evidence for a substantive negative effect of gender. Female MPs display on average a $5.34[1.60,9.10]$ per cent lower proportion of financial benefit-generating ties than male parliamentarians. This effect is likely a consequence of male-dominated networks ("old boy networks") and higher recruitment standards being applied to women (Geys and Mause 2012). ${ }^{13}$

Second, we find that more prior legislative experience on the regional level slightly decreases the share of financial benefit-generating ties. For every year served in a regional parliament MPs hold $0.28[0.03,0.52]$ per cent fewer positions at firms. This might indicate MPs' stronger focus on their political career and as a consequence, weaker links to relevant firms (cf. Becker et al. 2009).

Third and finally, we find a substantive effect for the policy specialisation of MPs on the IG type portfolio they cultivate. MPs who sit on financial and economic policy committees in parliament show a $4.65[3.01,6.32]$ per cent higher share of financial benefit-generating ties. This underlines the importance of parliamentarians' areas of expertise when deciding on an IG tie portfolio.

\section{[Table 3 about here]}

\section{Discussion and Conclusion}

The goal of this study was to explore MPs' interest group tie portfolios in relation to their ideology, legislative tenure and the interplay between these two on the basis of a utility perspective. We sought to explain why certain kinds of MPs accumulate either relatively more political benefit-generating or financial benefit-generating interest group ties over the course of their careers. These results contribute to our understanding of the micro-level foundations of parliamentarians' decision to collaborate with interest groups. Taken together, our study offers three key findings, each with theoretical implications.

\footnotetext{
13 Alternatively, women MPs in rightist parties are usually on average to the left of their male colleagues,
} thus making them less attractive to firms. 
Our first key finding is that centre and right-leaning MPs hold higher shares of firm board positions than left-leaning MPs. This finding supports our theoretical argument that left-leaning MPs' fear of vote penalties might stop them from accepting or seeking financial benefit-generating ties with interest groups. We already know from earlier work (Klüver 2018) that the preferences of the electorate play a role in how parties react to interest group demands. Our results show that a similar dynamic exists on the level of individual politicians. Parliamentarians also demonstrate responsiveness to their partisan electorate when forming relationships with interest groups.

Our finding that left-leaning MPs devote less time to firms also echoes previous studies that have addressed the role of ideological alignment in party-IG collaboration (Koger et al. 2009; Otjes and Rasmussen 2016) and parliamentarian-IG collaboration (Hall and Deardorff 2006; Wonka 2017; Wonka and Haunss 2019). The literature so far has emphasised that congruence of policy preferences between members of the dyad, i.e. parliamentarians and IGs, matters. Our results suggest that ideology matters beyond the MP-IG dyad. They show that parliamentarians also consider the ideological congruence between their potential interest group partners and their principals - voters and the party selectorate - when deciding on working with IGs. Left-leaning MPs may hence not (only) shy away from pursuing firm board positions out of an inhibition to betray their political ideals (Eggers and Hainmueller 2009: 530) or a stronger common goods orientation (Mause 2009: 156) but also to avoid falling from their principals' grace.

A second key finding is that, for the average MP in our data, we observed an increase in the proportion of financial benefit-generating ties when they stay longer in parliament. This supports our hypothesised mechanism of an incumbency bonus that provides MPs with more leeway to seek out financial benefit-generating ties. This finding is particularly interesting because work in the moonlighting literature with regards to tenure effects has so far been inconclusive. The current literature supports two contradictory notions; arguing that higher tenure leads to more side jobs because of MPs' better networks (Mause 2009) and to lower extra-parliamentary income due to weakening ties to the relevant job markets (Becker et al. 2009). In our approach, we identify an alternative explanation. Our theory and results emphasise that it is not only supply-side factors- positioning on or access to the extraparliamentary job market - that are important. Rather, from the perspective of the MP, tenure moderates their demand for firm board positions by means of an incumbency bonus. 
Our third and final key finding is that the increase of financial benefit-generating ties with tenure is stronger for centre and right-leaning MPs. In contrast, this proportion decreases for left-leaning MPs. These findings help us further our understanding of MPs' perceptions of their electorate. We can infer from this result that as their tenure in parliament increases, firm board positions gain even more in attractiveness relative to political benefit-generating ties for centre and right-leaning MPs. For left-leaning MPs, it could have been the case that at some point, their parliamentary tenure (incumbency bonus) would become large enough that they can also afford to collaborate with firms. Our results, however, suggest that left-leaning MPs do not go beyond this "opportunism tipping point" in any stage of their parliamentary career.

Several cautionary remarks are in order. First, our theoretical model, while standing the first empirical tests, also comes with limitations. There are possible alternative explanations that may be invoked to explain certain aspects of our results, in particular for the static relation between ideology and the number of private ties $\left(H_{1}\right)$. A key premise of our theoretical model is that tie formation is ultimately driven by decisions taken by MPs. The pending empirical question is if the frequency of receiving offers is correlated with the frequency of accepting offers. Our interpretation of the results rests on the assumption that this is not the case. If future work would show this assumption to be incorrect, then an alternative explanation might apply. This would be that centre and right-leaning MPs are offered more positions by firms due to ideological proximity, and in turn, also accept more of these positions. Such an investigation was beyond to scope of the current article but deserves further attention.

A second caveat of the presented findings is that our test of ideological motives might also inadvertedly capture an alternative mechanism driven by how MPs deal with income drops. Indeed, the decision of MPs to include relatively more firm board positions in their portfolio might also be attributed to a relative difference in the income drop when entering parliament. If we hypothesise that centre and right-leaning MPs have higher preparliamentary earnings, then their motivation to compensate lost earnings with a higher share of financial benefit-generating ties would also be stronger. We unfortunately did not have access to any income data for our study.

Third, our focus on the relative proportion of financial benefit-generating ties made sense in the context of our current study. Arguably though, it also masked some interesting 
other trends. Our descriptive results for example revealed that left-leaning, in contrast to centre- and right-leaning MPs diverge in their propensity to increase the total number of ties over the course of their career. Our theoretical model cannot directly address why right-wing parliamentarians hold more ties overall. More extensive data on side job offers and time investment would be needed to address these dynamics.

Taken together with this current article, future work can build on the distinction between political and financial benefit-generating ties and their relative attractiveness in different institutional contexts. The knowledge that follows from studying these two motivations in conjunction will further our understanding of how parliamentarians prioritise different (extra-) parliamentary activities and their responsiveness to various principals.

\section{Acknowledgements}

Our special thanks go to Tobias Gysin and Adrian Sutter for their help with the data collection and to Stefanie Bailer, Rosie Campbell, Benjamin Huwyler, Felicity Turner-Zwinkels, Simon Weschle, Thomas Zittel, and three anonymous referees for their excellent comments on earlier versions of this manuscript. Financial support from the Swiss National Science Foundation (project "Parliamentary Careers in Comparison", no. 162427) is gratefully acknowledged.

\section{Supporting Information}

The data that supports the findings of this study are available in the supplementary material of this article. 


\section{References}

Ansolabehere, S. and J. M. J. Snyder (2002). The Incumbency Advantage in U.S. Elections: An Analysis of State and Federal Offices, 1942-2000. Election Law Journal: Rules, Politics, and Policy 1(3): 315-338.

Arnold, F., B. Kauder and N. Potrafke (2014). Outside earnings, absence, and activity: Evidence from German parliamentarians. European Journal of Political Economy 36: 147-157.

Baeriswyl, O. (2005). Parlamentarierbefragung 2004/2005. Unpublished Manuscript. Villarssur-Glâne.

Bailer, S. (2011). People's Voice or Information Pool? The Role of, and Reasons for, Parliamentary Questions in the Swiss Parliament. The Journal of Legislative Studies 17(3): 302-314.

Becker, J., A. Peichl and J. Rincke (2009). Politicians' outside earnings and electoral competition. Public Choice 140(3): 379-394.

Cain, B. E. (1987). The personal vote : constituency service and electoral independence. Cambridge (Mass.), London: Harvard University Press.

Campbell, R. and P. Cowley (2015). Attitudes to Moonlighting Politicians: Evidence from the United Kingdom. Journal of Experimental Political Science 2(01): 63-72.

Chappell, H. W. (1981). Conflict of interest and congressional voting: A note. Public Choice 37(2): 331-335.

Diermeier, D., M. Keane and A. Merlo (2005). A Political Economy Model of Congressional Careers. American Economic Review 95(1): 347-373.

Djankov, S., R. La Porta, F. Lopez-de-Silanes and A. Shleifer (2010). Disclosure by Politicians. American Economic Journal: Applied Economics 2(2): 179-209.

Döring, H. and P. Manow (2018). Parliaments and governments database (ParlGov): Information on parties, elections and cabinets in modern democracies. Development version.

Downs, A. (1957). An Economic Theory of Political Action in a Democracy. Journal of Political Economy 65(2): 135-150.

Eggers, A. C. and J. Hainmueller (2009). MPs for Sale? Returns to Office in Postwar British Politics. American Political Science Review 103(4): 513-533.

Fischer, M., F. Varone, R. Gava and P. Sciarini (2019). How MPs ties to interest groups matter for legislative co-sponsorship. Social Networks 57: 34-42.

Fouirnaies, A. (2018). When Are Agenda Setters Valuable? American Journal of Political Science 62(1): 176-191. 
Fouirnaies, A. and A. B. Hall (2014). The Financial Incumbency Advantage: Causes and Consequences. The Journal of Politics 76(3): 711-724.

Fouirnaies, A. and A. B. Hall (2018). How Do Interest Groups Seek Access to Committees? American Journal of Political Science 62(1): 132-147.

Gagliarducci, S., T. Nannicini and P. Naticchioni (2010). Moonlighting politicians. Journal of Public Economics 94(9-10): 688-699.

Gallati, R. (2005). Professionalisierung als Maxime. In Baeriswyl, O. (ed.), Lobbying in der Schweiz : Partikulärinteressen unter der Bundeskuppel. Villars-Sur-Glâne: Mediata (77105).

Gava, R., F. Varone, A. Mach, S. Eichenberger, J. Christe and C. Chao-Blanco (2016). Interests groups in Parliament: Exploring MPs' interest affiliations (2000-2011). Swiss Political Science Review 23(1): 77-94.

Gelman, A. and G. King (1990). Estimating Incumbency Advantage without Bias. American Journal of Political Science 34(4): 1142-1164.

Geys, B. (2013). Election Cycles in MPs' outside Interests? The UK House of Commons, 20052010. Political Studies 61(2): 462-472.

Geys, B. and K. Mause (2012). Are Female Legislators Different? Exploring Sex Differences in German MPs' Outside Interests. Parliamentary Affairs: 1-25.

Geys, B. and K. Mause (2013). Moonlighting Politicians: A Survey and Research Agenda. The Journal of Legis/ative Studies 19(1): 76-97.

Grossmann, M. and C. B. K. Dominguez (2009). Party Coalitions and Interest Group Networks. American Politics Research 37(5): 767-800.

Hall, R. L. and A. V. Deardorff (2006). Lobbying as Legislative Subsidy. The American Political Science Review 100(1): 69-84.

Hurka, S., W. T. Daniel and L. Obholzer (2018). Determinants of moonlighting in the European Parliament. The Journal of Legislative Studies 24(1): 127-147.

Kerr, H. H. (1981). Parlement et société en Suisse. Saint-Saphorin: Georgi.

Klüver, H. (2018). Setting the Party Agenda: Interest Groups, Voters and Issue Attention. British Journal of Political Science: 1-22.

Koger, G., S. Masket and H. Noel (2009). Partisan Webs: Information Exchange and Party Networks. British Journal of Political Science 39(3): 633-653.

Kurtz, D. M. and M. A. Simon (2007). The education of the American political elite: 1949-2001. The Social Science Journal 44(3): 480-494.

Lachat, R. (2006). A Tale of Two Councils. Explaining the Weakness of the SVP in the Upper House of the Federal Parliament. Swiss Political Science Review 12(4): 77-99. 
Lowery, D., V. Gray, J. Anderson and A. J. Newmark (2004). Collective Action and the Mobilization of Institutions. The Journal of Politics 66(3): 684-705.

Lutz, G., A. Mach and R. Primavesi (2018). Interest Group Support and Electoral Success in the Swiss Elections of 2015. A Candidate Survey Analysis. Swiss Political Science Review 24(4): 487-509.

Mach, A., F. Varone, R. Gava and S. Eichenberger (2017). Database on Interest Groups in the Swiss Parliament. Data gathered at the Universities of Lausanne and Geneva, in the context of a research project funded by the SNF (100018_149689-1).

Maddox, H. W. J. (2004). Opportunity Costs and Outside Careers in U.S. State Legislatures. Legislative Studies Quarterly 29(4): 517-544.

Marquis, L. (2010). Understanding Political Knowledge and its Influence on Voting Preferences in the 2007 Federal Election. Swiss Political Science Review 16(3): 425-456.

Mause, K. (2009). Nebentätige Bundestagsabgeordnete: Was offenbaren die Veröffentlichungspflichten? Perspektiven der Wirtschaftspolitik 10(2): 146-174.

Neff Powell, E. and J. Grimmer (2016). Money in Exile: Campaign Contributions and Committee Access. The Journal of Politics 78(4): 974-988.

Niessen, A. and S. Ruenzi (2010). Political Connectedness and Firm Performance: Evidence from Germany. German Economic Review 11(4): 441-464.

Otjes, S. and A. Rasmussen (2016). The collaboration between interest groups and political parties in multi-party democracies. Party Politics 23(2): 96-109.

Sciarini, P., F. Varone, G. Ferro-Luzzi, F. Cappelletti, V. Garibian and I. Muller (2017). Studie über das Einkommen und den Arbeitsaufwand der Bundesparlamentarierinnen und Bundesparlamentarier. Département de science politique et relations internationales und Institut de recherche appliquée en économie et gestion (IREG), University of Geneva. Online: https://www.parlament.ch/centers/documents/de/studieeinkommen-arbeitsaufwand-parlamentarier-2017-d.pdf.

Staat, C. and C. R. Kuehnhanss (2016). Outside Earnings, Electoral Systems and Legislative Effort in the European Parliament. JCMS: Journal of Common Market Studies 55(2): $368-386$.

van Aelst, P., A. Sehata and A. van Dalen (2010). Members of Parliament: Equal Competitors for Media Attention? An Analysis of Personal Contacts Between MPs and Political Journalists in Five European Countries. Political Communication 27(3): 310-325.

Wittman, D. (1977). Candidates with policy preferences: A dynamic model. Journal of Economic Theory 14(1): 180-189.

Wittman, D. (1983). Candidate Motivation: A Synthesis of Alternative Theories. American Political Science Review 77(1): 142-157. 
Wonka, A. (2017). German MPs and interest groups in EU multilevel policy-making: the politics of information exchange. West European Politics 40(5): 1004-1024.

Wonka, A. and S. Haunss (2019). Cooperation in networks: Political parties and interest groups in EU policy-making in Germany. European Union Politics.

Z'graggen, H. and W. Linder (2004). Professionalisierung der Parlamente im internationalen Vergleich. Studie im Auftrag der Parlamentsdienste der Schweizerischen Bundesversammlung. Bern: Institut für Politikwissenschaft. 


\section{Biographies}

Oliver Huwyler is a PhD candidate in the Political Science Department in the University of Basel. His research interests include interest representation and lobbying, responsiveness, and parliamentary behaviour. E-mail: oliver.huwyler@unibas.ch

Tomas Turner-Zwinkels is a Postdoctoral Research Fellow in the Political Science Department in the University of Basel. His research interests include the concept of political human capital, gender equality, and the formal modelling of political career decisions. E-mail: tomas.turner-zwinkels@unibas.ch 


\section{Tables}

Table 1: Interest Group Types and Benefit Classification

\begin{tabular}{|c|c|c|c|c|}
\hline \multirow{2}{*}{ Interest Group Type } & \multirow{2}{*}{ Description } & \multirow{2}{*}{$\begin{array}{l}\text { Board Seat } \\
\text { Eligibility }\end{array}$} & \multicolumn{2}{|c|}{ Primary Benefit } \\
\hline & & & Political & Financial \\
\hline Private firm & Fully privately-owned company & Unrestricted & & $\sqrt{ }$ \\
\hline Union & $\begin{array}{l}\text { Organisation of non-profession specific } \\
\text { workers }\end{array}$ & Unrestricted & $\sqrt{ }$ & \\
\hline $\begin{array}{l}\text { Occupational } \\
\text { organisation }\end{array}$ & $\begin{array}{l}\text { Association of workers of the same / } \\
\text { similar professions }\end{array}$ & Unrestricted & $\sqrt{ }$ & \\
\hline Identity group & $\begin{array}{l}\text { Organisations of supporters with a } \\
\text { shared identity }\end{array}$ & Unrestricted & $\sqrt{ }$ & \\
\hline Hobby / leisure group & $\begin{array}{l}\text { Organisations of supporters with a } \\
\text { common sport / leisure interest }\end{array}$ & Unrestricted & $\sqrt{ }$ & \\
\hline Religious group & $\begin{array}{l}\text { Organisation of supporters united by a } \\
\text { shared religion }\end{array}$ & Unrestricted & $\sqrt{ }$ & \\
\hline Public interest group & $\begin{array}{l}\text { Organisation of supporters with a } \\
\text { shared interest in group goals }\end{array}$ & Unrestricted & $\sqrt{ }$ & \\
\hline $\begin{array}{l}\text { Institutional } \\
\text { organisation }\end{array}$ & $\begin{array}{l}\text { Association of public authorities and } \\
\text { institutions }\end{array}$ & Unrestricted & $\sqrt{ }$ & \\
\hline $\begin{array}{l}\text { Business / trade } \\
\text { association }\end{array}$ & Association of business actors & Unrestricted & $\sqrt{ }$ & $\sqrt{ }$ \\
\hline $\begin{array}{l}\text { Semi-independent } \\
\text { agency }\end{array}$ & $\begin{array}{l}\text { Public institution that resembles an } \\
\text { administration in its behaviour. Not- } \\
\text { for-profit with goals defined by the } \\
\text { state }\end{array}$ & $\begin{array}{l}\text { Restriction to } \\
\text { holders of specific } \\
\text { political offices } \\
\text { possible }\end{array}$ & $\sqrt{ }$ & \\
\hline Public firm & $\begin{array}{l}\text { Company that is at least partially } \\
\text { owned by a public sector actor }\end{array}$ & $\begin{array}{l}\text { Restriction to } \\
\text { holders of specific } \\
\text { political offices } \\
\text { possible }\end{array}$ & & $\sqrt{ }$ \\
\hline
\end{tabular}

Note: Descriptions adapted from labels developed by Mach et al. (2017). 
Table 2: Variable Overview

\begin{tabular}{|c|c|c|c|c|}
\hline Dependent variable & $\mathbf{N}$ & Categories / Range & Mean / \% & Std. Dev. \\
\hline Proportion of firm board positions & 6225 & $0-100$ & 35.63 & 38.29 \\
\hline \multicolumn{5}{|l|}{ Key independent variables } \\
\hline Left-right & 6192 & $0-10$ & 4.86 & 2.34 \\
\hline Tenure & 6225 & $0-38$ & 6.32 & 5.4 \\
\hline \multicolumn{5}{|l|}{ Contextual controls } \\
\hline Election year & 6225 & $\begin{array}{c}0=\text { not election year } \\
1=\text { election year }\end{array}$ & $15.02 \%$ & 0.36 \\
\hline \multirow[t]{2}{*}{ Seat safety } & 6221 & $0-11$ & 0.93 & 1.54 \\
\hline & & $0=$ not last term & $65.73 \%$ & \\
\hline \multirow[t]{2}{*}{ Last term } & 6225 & 1 = planned last term & $23.74 \%$ & - \\
\hline & & 2 = unplanned last term & $10.52 \%$ & \\
\hline District magnitude & 6225 & $1-35$ & 15.97 & 11.01 \\
\hline \multicolumn{5}{|l|}{ Individual controls } \\
\hline Female & 6225 & $\begin{array}{c}0=\text { male } \\
1=\text { female }\end{array}$ & $21.93 \%$ & 0.41 \\
\hline Lawyer & 6225 & $\begin{array}{c}0=\text { other profession } \\
1=\text { lawyer }\end{array}$ & $16.50 \%$ & 0.37 \\
\hline Firm-relevant committee & 6225 & $\begin{array}{c}0=\text { no relevant committee } \\
1=\text { economic } / \text { finance } \\
\text { committee }\end{array}$ & $26.54 \%$ & 0.44 \\
\hline Tenure in regional parliament & 6225 & $0-41$ & 5.43 & 5.44 \\
\hline Tenure in regional government & 6225 & $0-17$ & 0.48 & 2.24 \\
\hline Pension age & 6222 & $\begin{array}{c}0=64 \text { or younger } \\
1=65 \text { or older }\end{array}$ & $4.98 \%$ & 0.22 \\
\hline $\begin{array}{l}\text { Proportion of firm board positions } \\
\text { at entry }\end{array}$ & 6225 & $0-1$ & 0.31 & 0.41 \\
\hline
\end{tabular}


Table 3: Random Intercept Models Explaining MPs' Proportion of Firm Board Positions

\begin{tabular}{|c|c|c|c|c|c|c|c|}
\hline & Model 0 & Model 1 & Model 2 & Model 3 & Model 4 & Model 5 & Model 6 \\
\hline 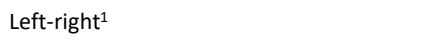 & & $2.153^{* * *}(0.33)$ & & $2.304^{* * *}(0.329)$ & $2.323^{* * *}(0.328)$ & $2.037^{* * *}(0.339)$ & $2.080^{* * *}(0.338)$ \\
\hline Tenure & & & $0.233^{* *}(0.075)$ & $0.259^{* * *}(0.075)$ & $0.354^{* * *}(0.092)$ & $0.218^{* *}(0.076)$ & $0.303^{* *}(0.093)$ \\
\hline Left-right*tenure & & & & $0.129 * * *(0.026)$ & $0.142^{* * *}(0.026)$ & $0.130^{* * *}(0.027)$ & $0.143^{* * *}(0.027)$ \\
\hline Election year & & & & & $4.586^{* * *}(1.069)$ & & $4.274^{* * *}(1.053)$ \\
\hline Seat safety & & & & & $-0.944^{* * *}(0.274)$ & & $-1.002 * * *(0.274)$ \\
\hline Planned last term² & & & & & $-1.361(0.847)$ & & $-0.976(0.858)$ \\
\hline Unplanned last term² & & & & & $-2.517^{*}(1.211)$ & & $-2.347+(1.21)$ \\
\hline District magnitude & & & & & $-0.129+(0.071)$ & & $-0.115(0.072)$ \\
\hline Female & & & & & & $-5.961 * *(1.913)$ & $-5.341^{* *}(1.918)$ \\
\hline Lawyer & & & & & & $2.687(1.695)$ & $2.364(1.696)$ \\
\hline Committee membership & & & & & & $4.659 * * *(0.843)$ & $4.657^{* * *}(0.843)$ \\
\hline Tenure in regional parliament & & & & & & $-0.242+(0.126)$ & $-0.277^{*}(0.127)$ \\
\hline Tenure in regional government & & & & & & $0.411(0.346)$ & $0.394(0.345)$ \\
\hline Pension age & & & & & & $-2.002(1.537)$ & $-1.834(1.562)$ \\
\hline Proportion of firm board positions at entry & & $0.649 * * *(0.02)$ & $0.679^{* * *}(0.02)$ & $0.645^{* * *}(0.02)$ & $0.646^{* * *}(0.02)$ & $0.631 * * *(0.020)$ & $0.633^{* * *}(0.020)$ \\
\hline Intercept & $35.145^{* * *}(1.383)$ & $35.083^{* * *}(0.955)$ & $35.144^{* * *}(1.001)$ & $35.369 * * *(0.993)$ & $35.574^{* * *}(1.123)$ & $35.278^{* * *}(1.101)$ & $35.272^{* * *}(1.215)$ \\
\hline \multicolumn{8}{|l|}{ Random effects } \\
\hline$\sigma^{2}$ & 362.44 & 346.97 & 345.52 & 344.93 & 342.81 & 343.22 & 341.09 \\
\hline Individual $\tau_{00}$ & 1133.70 & 372.97 & 399.18 & 368.70 & 365.80 & 363.05 & 361.18 \\
\hline Year $\tau_{00}$ & 11.31 & 10.30 & 11.84 & 12.56 & 16.23 & 10.13 & 13.49 \\
\hline \multicolumn{8}{|l|}{ Diagnostics } \\
\hline Observations & 6225 & 6011 & 6044 & 6011 & 6011 & 6008 & 6008 \\
\hline Log Likelihood & $-28,397.330$ & $-26,932.900$ & $-27,092.850$ & $-26,919.390$ & $-26,900.560$ & $-26,878.330$ & $-26,860.550$ \\
\hline Bayesian Information Criterion & $56,829.600$ & $53,918.020$ & $54,237.940$ & $53,908.390$ & $53,914.230$ & $53,878.480$ & $53,886.410$ \\
\hline Marginal R² / Conditional R² & $0.000 / 0.760$ & $0.521 / 0.772$ & $0.507 / 0.775$ & $0.526 / 0.775$ & $0.527 / 0.777$ & $0.534 / 0.777$ & $0.535 / 0.779$ \\
\hline
\end{tabular}

Note: Significance codes: $+p<0.1 ; *<0.05 ; * *<0.01 ; * * p<0.001 . \sigma^{2}=$ within-cluster variance, $\tau_{00}=$ between-cluster variance. Continuous variables are mean-centred.

${ }^{1}$ Higher scores $=$ more right-leaning; ${ }^{2}$ Base: Not last term. 


\section{Figures}

Figure 1: Utility Derived from Two Types of IG Ties Under Different Conditions
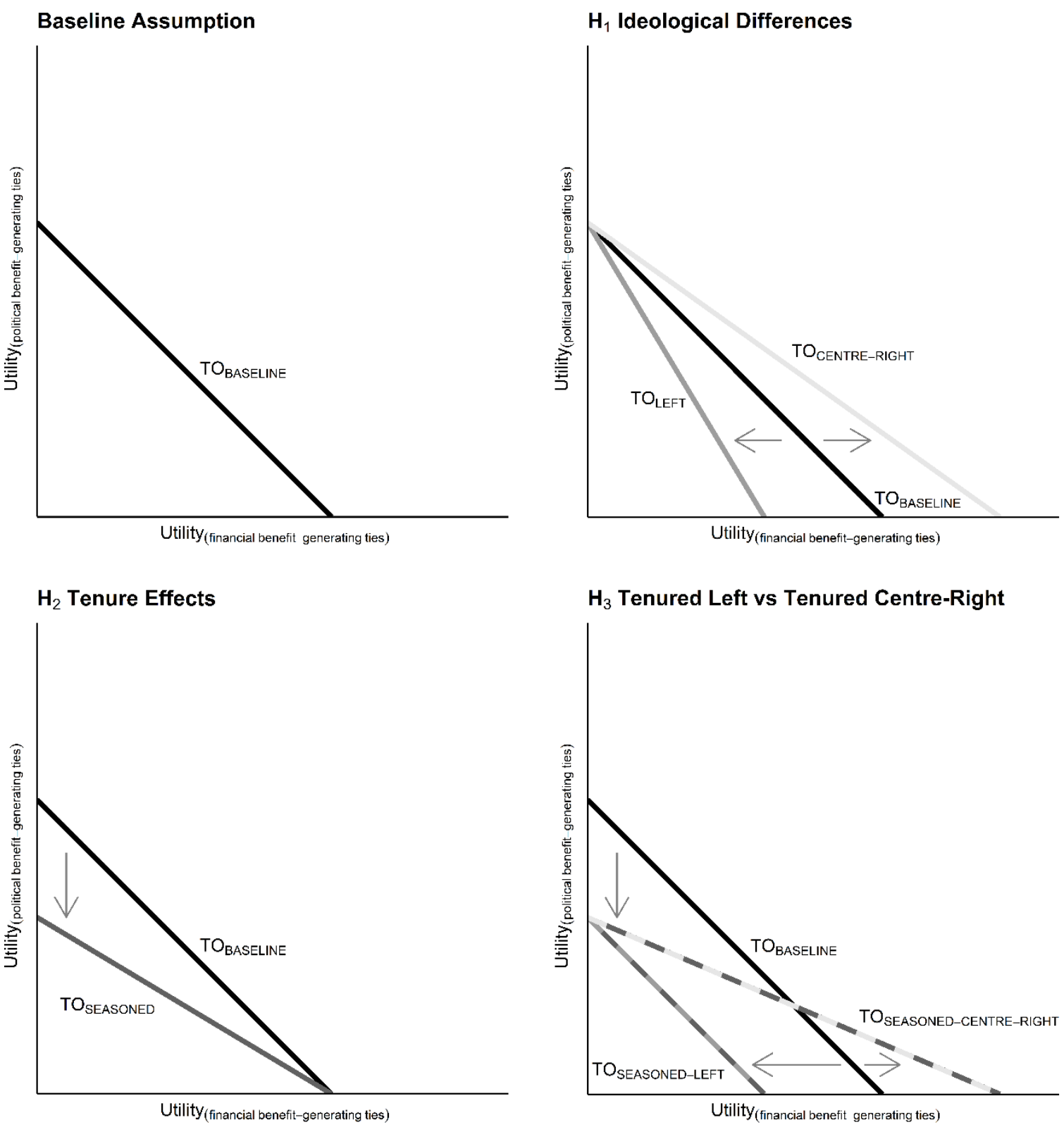

Note: TO denotes the trade-off line (analogous to the budget line in consumer theory) for possible utility combinations from financial benefit-generating and political benefit-generating ties. A relative shift of the point where the trade-off line crosses the $x$-axis is indicative of the increased/decreased investment in financial benefit-generating ties. In the same vein, shifts on the $y$-axis reveal changes in the relative investment in political benefit-generating ties.

TO $_{\text {BASELINE }}=$ Trade-off line for a non-partisan newcomer to parliament where both tie types are perfect substitutes; TOCENTRE-RIGHT = Trade-off line for a centre-right-wing MP; TOLEFT = Trade-off line for a left-wing MP; TOSEASONED $_{\text {S }}$ Trade-off line for a long-term MP; TOSEASONED-LEFT and TOSEASONED-CENTRE-RIGHT $=$ Trade-off lines for the respective interactions. 
Figure 2: Development of MPs' IG Tie Types Over Tenure

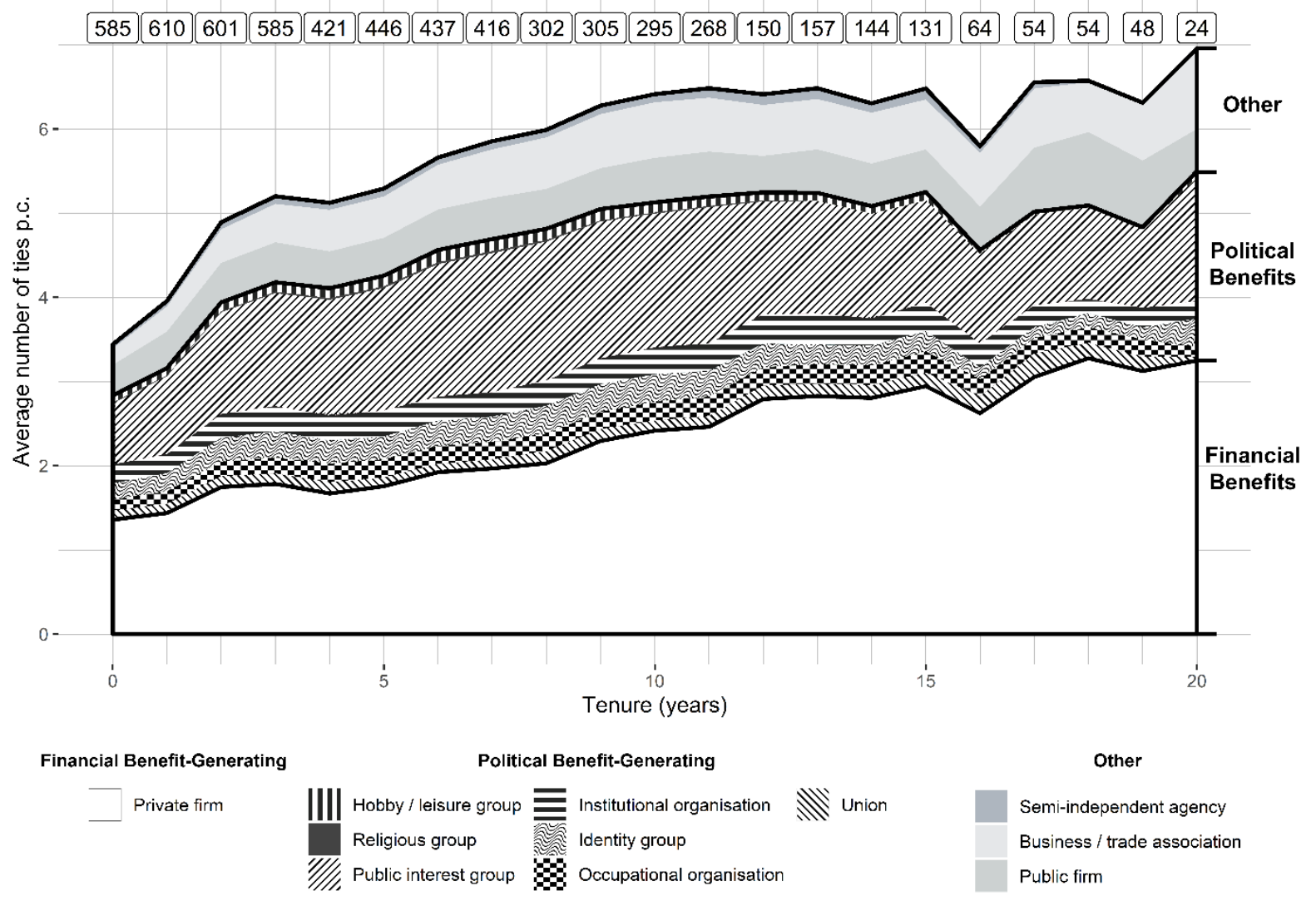

Note: $\mathrm{N}=6225$. The number of observations per tenure-year is indicated above the graph. 
Figure 3: Development of MPs' IG Tie Types over Tenure Separated According to Ideology

\section{Left-Leaning MPs}

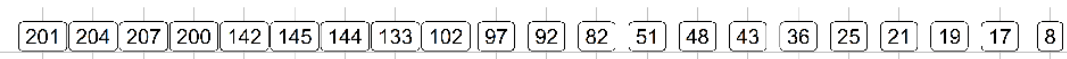

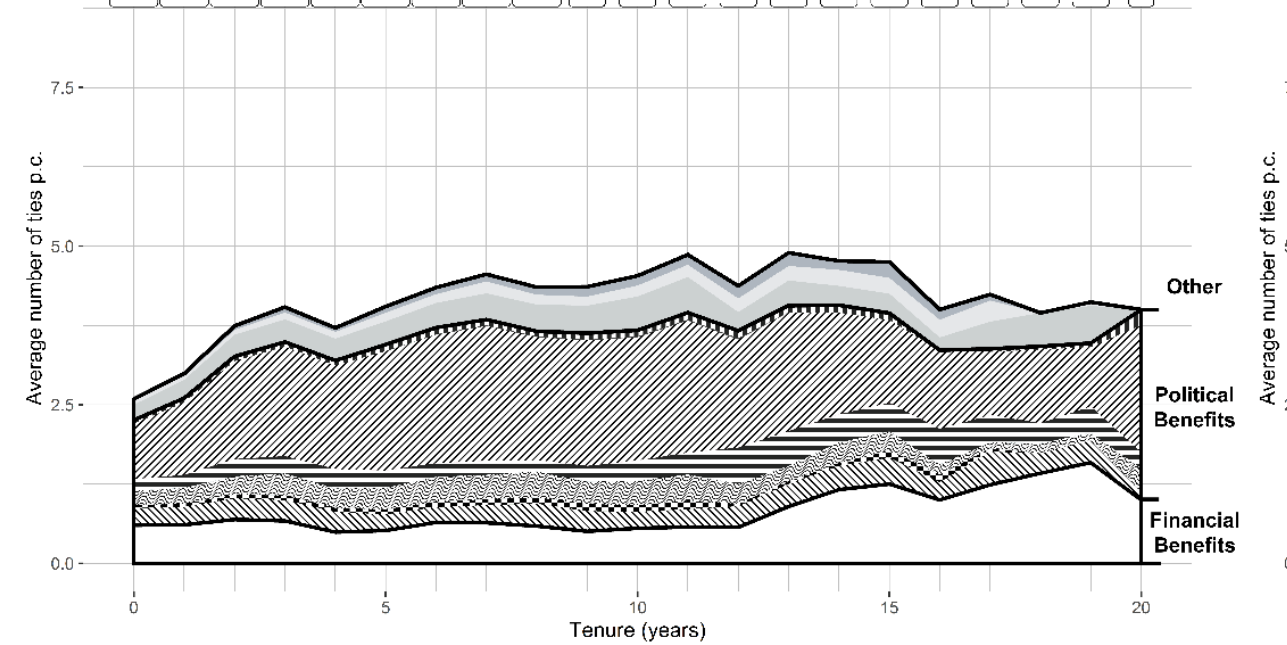

Financial Benefit-Generating

$\square$ Private firm

\section{Centre and Right-Leaning MPs}

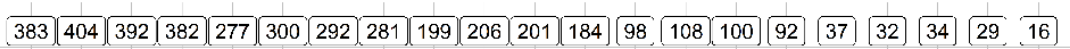

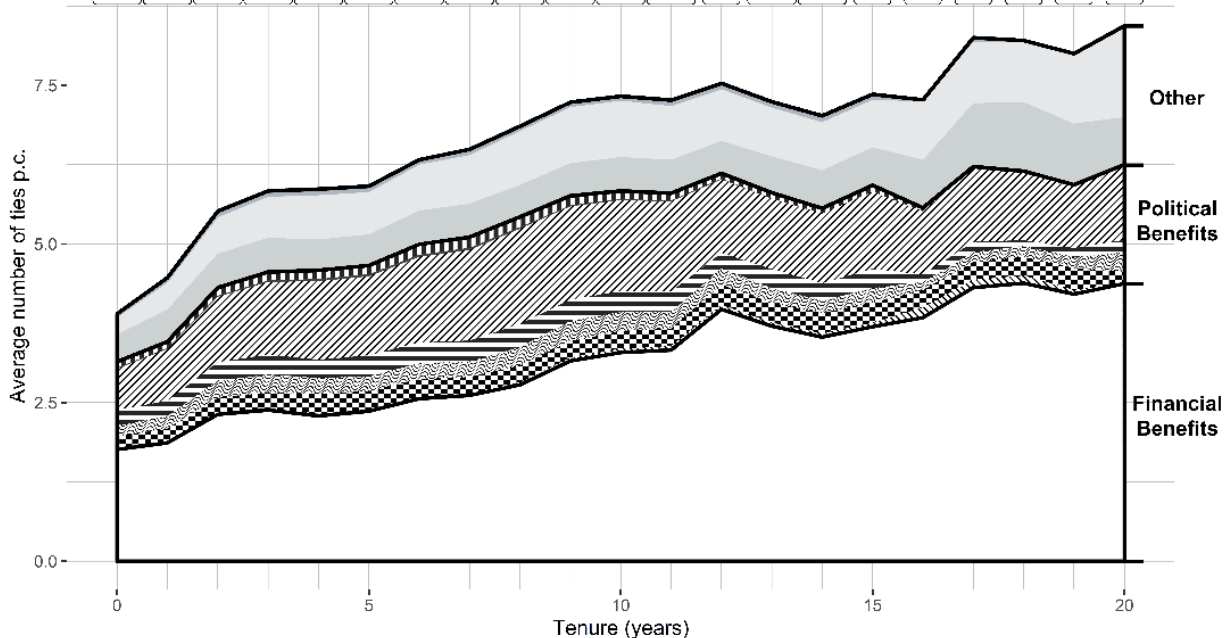

Other

Semi-independent agency Business / trade association

Public firm

Note: Left-leaning MPs encompass parliamentarians from parties with a left-right score $<4.729(\mathrm{~N}=2066)$. Centre and right-leaning MPs encompass parliamentarians with a left-right score $>=4.729(\mathrm{~N}=4126)$. 
Figure 4: Marginal Effects for the Interaction of Tenure and Left-Right

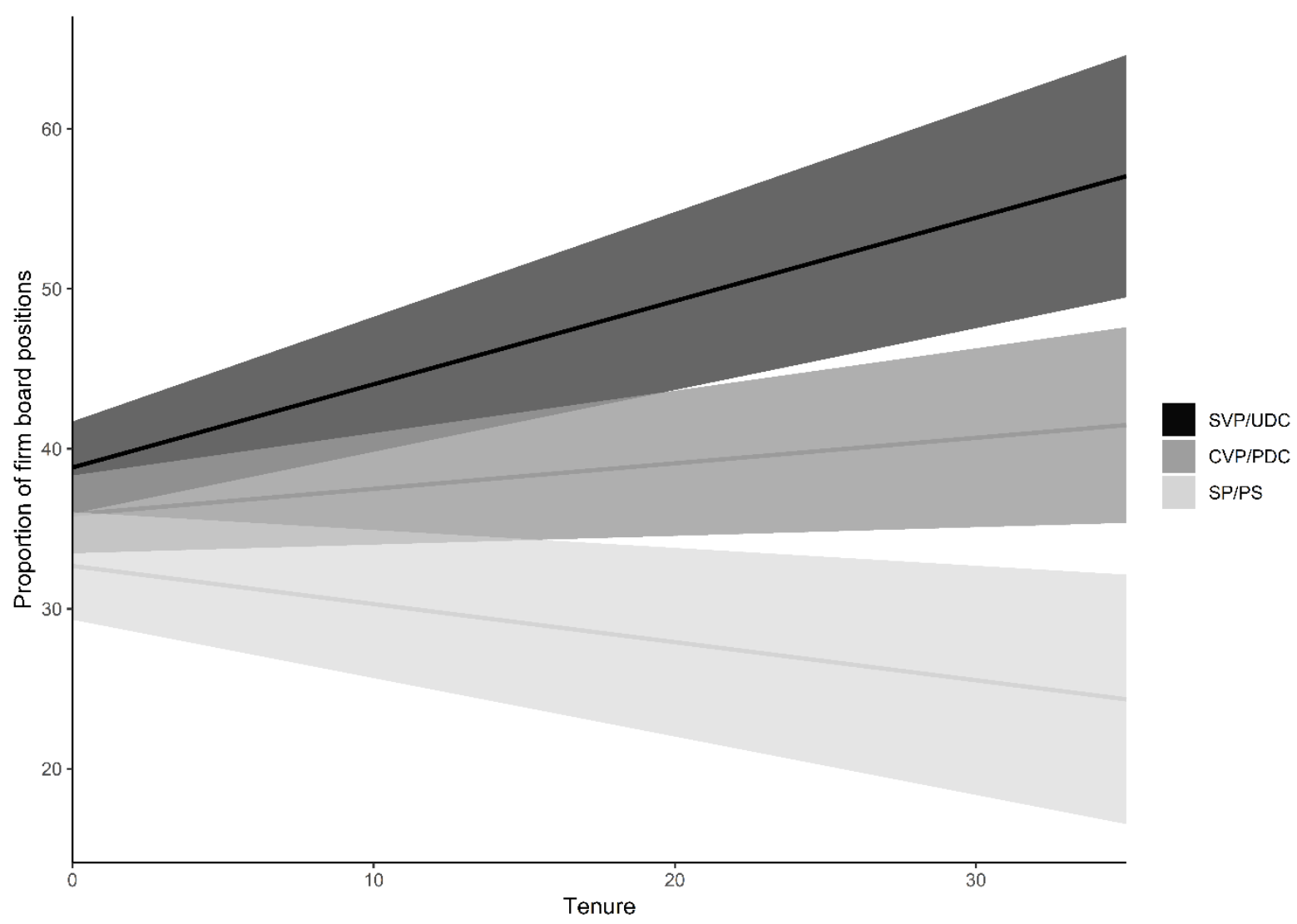

Note: Predictions are based on Model 6 without mean-centred variables. Left-right scores used in the figure: SVP/UDC (national conservatives): 7.357; CVP/PDC (Christian democrats): 4.729; SP/PS (social democrats):1.832. 95\% confidence intervals calculated using the Delta Method. 